\title{
Effect of Garlic Supplementation on the Blood Biochemical Profile of Murrah Buffalo Calves
}

\author{
Mohan Vamsi Duvvu ${ }^{1 *}$, K. Ananda Rao ${ }^{2}$, Ch. Venkata Seshaiah ${ }^{3}$ and \\ D. Srinivas Kumar ${ }^{4}$ \\ ${ }^{1}$ Department of Livestock Production Management, ${ }^{3}$ Department of Livestock Farm Complex, \\ ${ }^{4}$ Department of Animal Nutrition, N.T.R. College of Veterinary Science, Gannavaram, \\ Krishna district, Andhra Pradesh, India \\ ${ }^{2}$ Buffalo Research Station, Venkataramannagudem, West Godavari, Andhra Pradesh, India \\ *Corresponding author
}

A B S T R A C T

\begin{tabular}{|c|}
\hline Keywords \\
\hline $\begin{array}{l}\text { Garlic supplementation, } \\
\text { Murrah buffalo calves, } \\
\text { Blood biochemical } \\
\text { profile, Glucose, Serum } \\
\text { cholesterol, Serum total } \\
\text { protein }\end{array}$ \\
\hline Article Info \\
\hline $\begin{array}{l}\text { Accepted: } \\
24 \text { February } 2018 \\
\text { Available Online: } \\
10 \text { March } 2018\end{array}$ \\
\hline
\end{tabular}

The present study was carried out to investigate the effect of different levels of garlic supplementation on the blood biochemical profile of Murrah buffalo calves. In a CRD model, 18 murrah buffalo calves in the age group of 4-5 months were randomly divided into three groups $\left(\mathrm{T}_{0}, \mathrm{~T}_{1}\right.$ and $\left.\mathrm{T}_{2}\right)$ with six calves in each group. The $\mathrm{T}_{0}$ group served as the control whereas the $T_{1}$ and $T_{2}$ groups were supplemented with garlic powder at the dose rate of 250 and $300 \mathrm{mg}$ per $\mathrm{kg}$ body weight, respectively for a period of 90 days. The results of the study revealed a significant $(\mathrm{P}<0.01)$ increase in the total protein, albumin, globulin and HDL-cholesterol levels and a significant $(\mathrm{P}<0.01)$ decrease in the blood glucose level, serum cholesterol level and SGOT levels in the garlic supplemented calves compared with the control group calves. In addition to this, no significant difference was observed between the garlic supplemented group calves and control group calves with respect to serum calcium, serum phosphorus and blood urinary nitrogen (BUN) values. Thus, by this study we can conclude that dietary supplementation of garlic improved the total protein, serum albumin, serum globulin and HDL-cholesterol values and decreased the serum glucose, serum cholesterol and SGOT values in the murrah buffalo calves.

\section{Introduction}

Blood biochemical parameters are major indices of the physiological, pathological and nutritional status of an animal and a slight change in the values when compared to the normal values could be used to interpret the metabolic state as well as the health status of the animals (Mitruka and Rawnshey, 1977; Babatunde et al., 1992; Lamorde, 1996; Ramprabhu et al., 2010). Adulugba and Joshua et al., (1994) have opinion that it is often difficult to asses the correct health status of an animal without recourse to its blood 
examination. The serum biochemical profile of animals is influenced by the quantity and quality feed supplements being offered and also by the level of anti-nutritional factors present in the feed (Oyawoye and Ogunkunle, 1998; Akinmutimi, 2004).

In recent years, dairy farmers worldwide are incorporating feed additives in the animals' diet to enhance the performance and health status of the calves. With the ban on the use of antibiotics by the European Commission, the livestock scientists have shifted their attention towards herbal feed additives/ herbal growth promoters (Jayasena and Jo, 2013). Most of the herbal feed additives belong to the class of isoprene derivatives, flavonoides and glucosinolates which act as natural antibiotics or anti-oxidants (Rhodes, 1996 or Hirasa and Takemasa, 1998). In farm animals, herbal growth promoters serve as appetizers, digestive stimulants, antibacterial, antiviral, antihelmintic, anti-inflammatory and also possess immuno-stimulation properties (Platel et al., 2002; Wenk, 2003).

Garlic (Allium sativum) has been a subject of considerable interest as a medicinal and therapeutic agent globally since ancient times. It was used as a remedy for intestinal disorders, flatulence, worms, respiratory infections, skin diseases, wounds, symptoms of ageing and many other ailments. The main pharmacological effects of garlic are attributed to 'allicin', an organosulphur compound that exhibits antibacterial (Lanzotti, 2006; Toghyani et al., 2011), antifungal, antiparasitic, antiviral (Ankri and Mirelman, 1999), antioxidant (Banerjee et al., 2003; Lee et al., 2009), hypocholesterolemic (Gupta and Porter, 2001), hypoglycemic and hypotensive action.

The hypoglycemic property of garlic was reported by Kumar and Reddy (1999) in rats and Singh et al., (2017) in broilers. Further the hypolipidemic property of garlic was demonstrated by Omojola et al., (2009) in pigs and Prasad et al., (2009) in broilers. Also, Garlic has the capacity to increase the total protein, albumin and globulin concentrations as evident by the findings of Hassan et al., (2013) in growing buffalo calves.

However, there is lack of convincing information on the effect of garlic supplementation on the blood biochemical profile in murrah buffalo calves. Hence it is against this background that the present study was conducted to evaluate the effect of varying levels of garlic powder supplementation on the blood biochemical profile of murrah buffalo calves.

\section{Materials and Methods}

\section{Experimental location}

The present experiment was carried out at Buffalo Research Station, Venkataramannagudem, West Godavari, Andhra Pradesh. This research station is located at $16.49^{\circ} \mathrm{N}$ latitude and $81.30^{\prime} \mathrm{E}$ and 18 metres above the mean sea level.

\section{Experimental animals and experimental design}

The present study was carried out on 18 Murrah buffalo calves of 4-5 months age, which were randomly allotted into 3 groups $\left(\mathrm{T}_{0}, \mathrm{~T}_{1}\right.$ and $\left.\mathrm{T}_{2}\right)$ of 6 animals in each group based on their body weight and sex in Completely Randomized Design.

The calves in the $T_{0}$ group served as control and the calves in the $T_{1}$ and $T_{2}$ group were supplemented with garlic powder at the dose rate of 250 and $300 \mathrm{mg}$ per $\mathrm{kg}$ body weight, respectively in their concentrate feed. The experiment was conducted for a period of 90 days. 


\section{Housing and feeding management}

All the experimental calves were housed individually in a well-ventilated shed with a provision for individual feeding and water facilities.

The calves were fed with chopped green fodder (Hybrid Napier) and concentrate mixture (calf grower) as the basal diet as per their body requirements.

\section{Preparation of garlic powder}

Garlic bulbs were purchased from the local market and were dried under the shade for a period of 15 days.

After drying, the outer husks were removed and the bulbs were ground to fine powder by using electrical mixer.

\section{Health management}

All the experimental calves were dewormed 10 days prior to the beginning of the experiment with Fenbendazole at the dose rate of $10 \mathrm{mg}$ per $\mathrm{kg}$ body weight and were vaccinated with Foot and Mouth disease vaccine during the second month of the experimental trial.

\section{Blood collection}

The blood samples were collected asceptically from the jugular vein of the calves. About 3 $\mathrm{ml}$ of blood is collected from each calf for serum biochemical analysis into clean vaccutainers.

This whole blood is allowed to clot by keeping it in slant position at $45^{\circ}$ angle for 30 minutes and then on centrifuging it at $4500 \mathrm{rpm}$ for 10 minutes, clear serum is obtained. This serum is used for estimating the biochemical profile of the experimental calves.

\section{Biochemical analysis}

The serum biochemical profile of the experimental calves was assessed at every fortnightly interval. Glucose, total protein, serum albumin, serum globulin, serum calcium, serum phosphorus, serum total cholesterol, High density lipoprotein (HDL) cholesterol, Blood urinary nitrogen (BUN) and Serum glutamic-oxoloacetic transaminase (SGOT) were estimated using ERBA kits and by using 'Spectrophotometer' (MULTISKAN GO, Thermoscientific, Japan).

\section{Analysis of data}

The data was analysed for significant differences among the groups for biochemical parameters using ANOVA and Post-hoc tests as implemented in SPSS version 16.0 (SPSS, 2008).

\section{Results and Discussion}

The results of the current study revealed a significant $(\mathrm{P}<0.01)$ decrease in the blood glucose levels in garlic supplemented calves compared with the control group (Table 1). This hypoglycaemic effect might be attributed to an increase in the pancreatic secretion of insulin from the beta cells (Jain and Vyas., 1975; Sodimu et al., 1984). Banerjee and Maulik (2002) revealed that allyl propyl disulphide-one of the active ingredients of garlic, may lower glucose by competing with insulin which results in increased free insulin. This increased insulin secretion causes an increase in the nitric oxide production and significantly decrease the inflammatory cytokines, glycosylated haemoglobin, post prandial blood glucose and fasting blood glucose level (Kumar et al., 2013). VazquezPrieto et al., (2011) and Ademiluyi et al., (2013) have opinion as S-allyl cysteine sulfoxide present in garlic is responsible for its hypoglycaemic activity. 
These results were supported by the findings of Kumar and Reddy (1999) in mice and Singh et al., (2017) in broilers. Contrary to the present findings, increase in the serum glucose concentration on garlic supplementation was reported by Pirmohammadi et al., (2014) in pre partum mahabadi goats and Kholif et al., (2012) in lactating goats. This increase in the serum glucose concentration might be due to enhancement of gluconeogenesis process by the garlic in the diet. However, Balamurugan et al., (2014) in crossbred calves and Chaves et al., (2008) in sheep did not notice any significant effect in the serum glucose levels on garlic supplementation in the diet.

Significant $(\mathrm{P}<0.01)$ improvement in the serum total protein, albumin and globulin values was noticed in garlic supplemented calves over the control group calves (Table 2, 3 and 4 respectively). The increase in the total protein level with relative increase in the albumin and globulin level may be attributed to the organosulphur compounds present in garlic and to their hepato-protective action (Ajayi et al., 2009).

These results were supported by the findings of Hassan et al., (2013) and Alagawany et al., (2016) in growing buffalo calves and rabbits respectively. Contrary to the present findings, garlic supplementation resulted in no significant improvement in the serum total protein, serum albumin and serum globulin levels in crossbred calves (Balamurugan et al., 2014), grazing lambs (Amin et al., 2014) and pigs (Chen et al., 2008 and Yan et al., 2011).

The results showed a significant $(\mathrm{P}<0.01)$ decrease in the serum cholesterol levels in garlic supplemented calves as compared with the control group (Table 5). This might be due to the inhibition of hepatic cholesterol synthesis. Garlic has hypocholesterolaemic action which is exhibited by depressing the hepatic activities of lipogenic and cholesterogenic enzymes such as malic enzyme, fatty acid synthase, glucose-6 phosphate dehydrogenase and 3-hydroxy-3methyl-glutaryl-CoA (HMG CoA) reductase (Qureshi et al., 1983, Mahmoud et al., 2010). This reduction in the serum cholesterol suggests the ability of garlic to lower some of the risk factors associated with the development of cardiovascular diseases in animals (Ademola et al., 2009).

Pirmohammadi et al., (2014) reported that garlic supplementation in the diet resulted in a decrease in the serum cholesterol level in mahabadi goats. Similar findings were observed by Omojola et al., (2009) and Yan et al., (2011) in weanling pigs and Rahimi et al., (2011) in broilers. However, garlic supplementation resulted in no significant decrease in the serum cholesterol levels in sheep (Anassori et al., 2015) and broilers (Carrijo et al., 2005).

The HDL-cholesterol levels were significantly $(\mathrm{P}<0.01)$ increased in the garlic supplemented calves as compared with the nonsupplemented calves (Table 6). This increase might be due to the hypocholesterolaemic mechanism and the hypolipidemic action of garlic powder. 'Allicin' present in garlic combines with the $-\mathrm{SH}$ (sulphadryl) group that is important in activation of Acetyl CoA which is essential for the biosynthesis of cholesterol (Puvaca et al., 2014). The current results are in agreement with the findings of Mirhadi et al., 1991 in rabbits, Rahimi et al., (2011) in broilers and Faisal Irshad et al., (2017) in male albino rats. Contrary to the present findings, decrease in the HDLcholesterol levels on garlic supplementation was reported by Azzaet al., (2012) in Zaraibi goats. However, no significant effect on the HDL-cholesterol levels on garlic supplementation was observed by Canogullari et al., (2009) and Ao. X et al., (2011) in laying hens and broilers, respectively. 
Table. 1 The Mean \pm SE and analysis of variance of blood glucose levels of murrah buffalo calves supplemented with different levels of garlic in the diet

\begin{tabular}{|l|c|c|c|}
\hline Time Interval & $\mathrm{T}_{0}$ group $(\mathrm{mg} / \mathrm{dl})$ & $\mathrm{T}_{1}$ group $(\mathrm{mg} / \mathrm{dl})$ & $\mathrm{T}_{2}$ group $(\mathrm{mg} / \mathrm{dll})$ \\
\hline $\mathbf{0}$ day & $85.68 \pm 3.87$ & $92.33 \pm 4.47$ & $94.56 \pm 5.58$ \\
\hline $90^{\text {th }}$ day $* *$ & $113.39 \pm 5.55^{\mathrm{a}}$ & $71.62 \pm 5.89^{\mathrm{b}}$ & $73.82 \pm 5.88^{\mathrm{b}}$ \\
\hline
\end{tabular}

Means with similar superscript doesn't differ significantly

** indicate $\mathrm{P}$ value $<0.01$

Table.2 The Mean \pm SE and analysis of variance of total protein values of murrah buffalo calves supplemented with different levels of garlic in the diet

\begin{tabular}{|l|c|c|c|}
\hline Time Interval & $\mathrm{T}_{0}$ group $(\mathrm{g} / \mathrm{dl})$ & $\mathrm{T}_{1}$ group $(\mathrm{g} / \mathrm{dl})$ & $\mathrm{T}_{2}$ group $(\mathrm{g} / \mathrm{dl})$ \\
\hline $0^{\text {th }}$ day & $4.63 \pm 0.14$ & $4.74 \pm 0.26$ & $4.97 \pm 0.10$ \\
\hline $90^{\text {th }}$ day $* *$ & $7.28 \pm 0.06^{\mathrm{a}}$ & $10.62 \pm 0.10^{\mathrm{b}}$ & $11.53 \pm 0.06^{\mathrm{c}}$ \\
\hline
\end{tabular}

Means with similar superscript doesn't differ significantly

** indicate $\mathrm{P}$ value $<0.01$

Table.3 The Mean \pm SE and analysis of variance of albumin levels of murrah buffalo calves supplemented with different levels of garlic in the diet

\begin{tabular}{|l|c|c|c|}
\hline Time Interval & $\mathrm{T}_{0}$ group $(\mathrm{g} / \mathrm{dl})$ & $\mathrm{T}_{1}$ group $(\mathrm{g} / \mathrm{dl})$ & $\mathrm{T}_{2}$ group $(\mathrm{g} / \mathrm{dl})$ \\
\hline $\mathbf{0}$ day & $2.31 \pm 0.15$ & $2.28 \pm 0.07$ & $2.09 \pm 0.06$ \\
\hline 90 $^{\text {th }}$ day $* *$ & $3.68 \pm 0.07^{\mathrm{a}}$ & $4.81 \pm 0.04^{\mathrm{b}}$ & $5.01 \pm 0.05^{\mathrm{c}}$ \\
\hline
\end{tabular}

Means with similar superscript doesn't differ significantly

** indicate $\mathrm{P}$ value $<0.01$

Table.4 The Mean \pm SE and analysis of variance of globulin levels of murrah buffalo calves supplemented with different levels of garlic in the diet

\begin{tabular}{|l|c|c|c|}
\hline Time Interval & $\mathrm{T}_{0}$ group $(\mathrm{g} / \mathrm{dl})$ & $\mathrm{T}_{1}$ group $(\mathrm{g} / \mathrm{dl})$ & $\mathrm{T}_{2}$ group $(\mathrm{g} / \mathrm{dl})$ \\
\hline 0 day & $2.32 \pm 0.13$ & $2.45 \pm 0.23$ & $2.88 \pm 0.12$ \\
\hline 90 $^{\text {th }}$ day $* *$ & $3.60 \pm 0.10^{\mathrm{a}}$ & $5.80 \pm 0.09^{\mathrm{b}}$ & $6.53 \pm 0.06^{\mathrm{c}}$ \\
\hline
\end{tabular}

Means with similar superscript doesn't differ significantly

** indicate $\mathrm{P}$ value $<0.01$

Table.5 The Mean \pm SE and analysis of variance of serum cholesterol levels of murrah buffalo calves supplemented with different levels of garlic in the diet

\begin{tabular}{|l|c|c|c|}
\hline Time Interval & To group $(\mathrm{mg} / \mathrm{dl})$ & $\mathrm{T}_{1}$ group $(\mathrm{mg} / \mathrm{dl})$ & $\mathrm{T}_{2}$ group $(\mathrm{mg} / \mathrm{dl})$ \\
\hline $\mathbf{0}$ day & $87.36 \pm 5.52$ & $92.44 \pm 4.98$ & $89.73 \pm 6.07$ \\
\hline $\mathbf{9 0}^{\text {th }}$ day $* *$ & $121.56 \pm 4.57^{\mathrm{a}}$ & $72.25 \pm 3.98^{\mathrm{b}}$ & $69.39 \pm 3.24^{\mathrm{b}}$ \\
\hline
\end{tabular}

Means with similar superscript doesn't differ significantly

** indicate $\mathrm{P}$ value $<0.01$ 
Table.6 The Mean \pm SE and analysis of variance of HDL-cholesterol levels of murrah buffalo calves supplemented with different levels of garlic in the diet

\begin{tabular}{|l|c|c|c|}
\hline Time Interval & $\mathrm{T}_{0}$ group $(\mathrm{mg} / \mathrm{dl})$ & $\mathrm{T}_{1}$ group $(\mathrm{mg} / \mathrm{dl})$ & $\mathrm{T}_{2}$ group $(\mathrm{mg} / \mathrm{dl})$ \\
\hline $\mathbf{0}$ day & $41.12 \pm 2.31$ & $42.44 \pm 1.92$ & $40.27 \pm 3.22$ \\
\hline $90^{\text {th }}$ day $* *$ & $124.44 \pm 2.37^{\mathrm{a}}$ & $177.97 \pm 2.53^{\mathrm{b}}$ & $186.54 \pm 0.91^{\mathrm{c}}$ \\
\hline
\end{tabular}

Means with similar superscript doesn't differ significantly ** indicate $\mathrm{P}$ value $<0.01$

Table.7 The Mean \pm SE and analysis of variance of BUN values of murrah buffalo calves supplemented with different levels of garlic in the diet

\begin{tabular}{|l|c|c|c|}
\hline Time Interval & To group $(\mathrm{mg} / \mathrm{dl})$ & $\mathrm{T}_{1}$ group $(\mathrm{mg} / \mathrm{dl})$ & $\mathrm{T}_{2}$ group $(\mathrm{mg} / \mathrm{dl})$ \\
\hline $\mathbf{0}$ day & $28.91 \pm 2.86$ & $24.54 \pm 1.36$ & $25.14 \pm 0.84$ \\
\hline $90^{\text {th }}$ day & $41.80 \pm 5.33$ & $43.09 \pm 4.32$ & $35.04 \pm 5.28$ \\
\hline
\end{tabular}

Table.8 The Mean \pm SE and analysis of variance of SGOT values of murrah buffalo calves supplemented with different levels of garlic in the diet

\begin{tabular}{|l|c|c|c|}
\hline Time Interval & To group (I.U) & T $_{1}$ group (I.U) & T $_{2}$ group (I.U) \\
\hline 0 day & $106.32 \pm 5.38$ & $109.45 \pm 5.98$ & $104.28 \pm 6.11$ \\
\hline $9^{\text {th }}$ day $* *$ & $119.56 \pm 5.86^{\mathrm{a}}$ & $76.69 \pm 5.32^{\mathrm{b}}$ & $74.45 \pm 5.79^{\mathrm{b}}$ \\
\hline
\end{tabular}

Means with similar superscript doesn't differ significantly ** indicate $\mathrm{P}$ value $<0.01$

Table.9 The Mean \pm SE and analysis of variance of serum calcium levels of murrah buffalo calves supplemented with different levels of garlic in the diet

\begin{tabular}{|l|c|c|c|}
\hline Time Interval & To group $(\mathbf{m g} / \mathrm{dl}))$ & $\mathrm{T}_{1}$ group $(\mathrm{mg} / \mathrm{dll})$ & $\mathrm{T}_{2}$ group $(\mathrm{mg} / \mathrm{dll})$ \\
\hline $\mathbf{0}$ day & $8.64 \pm 0.36$ & $8.28 \pm 0.23$ & $8.97 \pm 0.48$ \\
\hline $\mathbf{9 0} 0^{\text {th }}$ day & $12.08 \pm 0.54$ & $12.11 \pm 0.50$ & $12.36 \pm 0.56$ \\
\hline
\end{tabular}

Table.10 The Mean \pm SE and analysis of variance of serum phosphorus levels of murrah buffalo calves supplemented with different levels of garlic in the diet

\begin{tabular}{|l|c|c|c|}
\hline Time Interval & To group $(\mathrm{mg} / \mathrm{dl})$ & $\mathrm{T}_{1}$ group $(\mathrm{mg} / \mathrm{dl})$ & $\mathrm{T}_{2}$ group $(\mathrm{mg} / \mathrm{dl})$ \\
\hline $\mathbf{0}$ day & $4.32 \pm 0.22$ & $4.27 \pm 0.28$ & $4.39 \pm 0.35$ \\
\hline $90^{\text {th }}$ day & $6.47 \pm 0.31$ & $6.49 \pm 0.31$ & $6.54 \pm 0.32$ \\
\hline
\end{tabular}


The results of the current study showed there exist no significant difference in the BUN values between the garlic supplemented calves and non-supplemented calves (Table 7 ). The current results are supported by the findings of Amin et al., (2014) in grazing lambs, Anassori et al., (2015) in sheep and Balamurugan et al., (2014) in crossbred calves.

Contrary to the present findings, Onu and Aja (2011) in rabbits, reported a significant $(\mathrm{P}<0.01)$ increase in the BUN value on garlic supplementation in the diet. Likewise, a significant $(\mathrm{P}<0.01)$ decrease in the BUN value on garlic supplementation was reported by Ghalehkandi et al., (2012) in rats.

Garlic supplementation resulted in a significant $(\mathrm{P}<0.01)$ decrease in the SGOT levels in the garlic treated calves as compared with the control group calves (Table 8). Serum glutamic-oxoloacetic transaminase (SGOT) and serum glutamic-pyruvic transaminase (SGPT) enzymes are a relatively specific indicator of acute liver cell damage and pathological manifestation of liver dysfunction. They are released into the blood stream only when the liver is damaged. The organosulphur compounds present in garlic decrease the SGOT and SGPT levels, thus, indirectly protecting the liver from any damage and maintaining its integrity and function.

Alagawany et al., (2016) in rabbits, also reported a decrease in the SGOT levels on garlic supplementation in the diet. However, no positive influence of garlic supplementation on the SGOT levels was observed by El-katcha et al., (2016) and Onyimonyi et al., (2013) in fattening lambs and pigs, respectively.

No significant difference was observed in the serum calcium and phosphorus level in garlic treated calves over the control group calves (Table 9 and 10, respectively). This might be due to the inability of garlic to exert its effect on the calcium and phosphorus regulation mechanisms in the body. Similar results were observed by El-katcha et al., (2016), Pirmohammadi et al., (2014) and Zakeri et al., (2014) in fattening lambs, pre-partum goats and lactating goats, respectively.

Based on the above results, it can be concluded that dietary supplementation of garlic powder either at the dose rate of 250 $\mathrm{mg}$ or $300 \mathrm{mg}$ per $\mathrm{kg}$ body weight has a significant effect on the blood biochemical profile in murrah buffalo calves.

\section{References}

Ademiluyi, A. O., Oboh, G., Owoloye, T. R. and Agbebi, O. J. 2013. Modulatory effects of dietary inclusion of garlic (Allium sativum) on gentamycininduced hepatotoxicity and oxidative stress in rats. Asian Pacific Journal of Tropical Biomedicine 3: 470-475.

Ademola, S. G., Farinu, G. O. and Babatunde, G. M. 2009. Serum lipid, growth and haematological parameters of broilers fed garlic, ginger and their mixtures. World Journal of Agricultural Sciences.5: 99-104.

Adulugba, A.T., Joshua, R.A. 1994. Haematological studies in apparently normal breeds of goats in Nigeria, Bulletin of Animal Health and Production in Africa. 38: 59-64.

Ajayi, G. O., Adeniyi, T. T. and Babayemi, D. O. 2009.Hepatoprotective and some haematological effects of Allium sativum and vitamin $\mathrm{C}$ in lead-exposed wistar rats. International Journal of Medicine and Medical Sciences. 1: 6467.

Akinmutimi, A.H. 2004. Evaluation of sword bean (Canavalia gladiate) as alternative 
feed resourcesfor broiler chicken. $\mathrm{PH}$. D. Thesis. Michael Okpara University of Agriculture. Umudike Nigeria.

Alagawany, M., Ashour, E. A. and Reda, F. M. 2016. Effect of dietary supplementation of Garlic (Allium sativum) and Turmeric (Curcuma longa) on growth performance, carcass traits, blood profile and oxidative status in growing rabbits. Annals of Animal Science.16: 489-505.

Amin, A. B., Yousuf, M. B., Kolo, U. M., Ibrahim, A. A., Muhammad, A. I. and Maigado, A. I. 2014. Influence of Periodic Administration of Garlic Extract on Blood Parameters of Grazing Lambs. Biokemistri, 26: 114-119.

Anassori, E., Dalir- Naghadeh, B., Pirmohammadi, R. and Hadian, M. 2015. Changes in blood profile in sheep receiving raw garlic, garlic oil or monensin. Journal of Animal Physiology and Animal Nutrition.99: 114-122.

Ankri, S. and Mirelman, D. 1999. Antimicrobial properties of allicin from garlic. Microbes and infection. 1: 125129.

Ao, X., Yoo, J. S., Zhou, T. X., Wang, J. P., Meng, Q. W., Yan, L., Cho, J. H. and Kim, I. H. 2011. Effects of fermented garlic powder supplementation on growth performance, blood profiles and breast meat quality in broilers. Livestock Science. 141: 85-89.

Azza, M. K. and Awadalla, S. A. 2002. Effect of Garlic and/or Onion on the Production and Performance of Goats. Egyptian Society for Animal Production and Fertility -14th Annual congress in cooperation with Egyptian Veterinary Nutrition Association, Giza: 141-152.

Babatunde, G.M., Fajimi, A.O., Oyedeji A.O. 1992. Rubber seed oil versus palm oil in broiler chicken diets. Effects on performance, nutrient digestibility, haematology and carcass characteristics Animal Feed Science and Technology. 25:133-146.

Balamurugan, N., Sundaram, S. M., Sivakumar, T. and Rajkumar, J. S. I. 2014. Effect of Garlic (Allium sativum) Supplementation on the blood profile of Jersey crossbred calves. Indian Journal of Veterinary and Animal Sciences.10: 303-309.

Banerjee, S. K., Dinda, A. K., Manchanda, S. C. and Maulik, S. K. 2002. Chronic garlic administration protects rat heart against oxidative stress induced by ischemic reperfusion injury. BMC Pharmacology 2: 16.

Banerjee, S.K., Mukherjee, P.K. andMaulik, S.K. 2003. Garlic as an antioxidant: the good, the bad and the ugly. Phytother. Res., 17(2): 97-106.

Canogullari, S., Karaman, M., Erdogan, Z E Y N E P, Baylan M I K A I L, Kucukgul, A., Duzguner, V. and Kemali Ozugur, A. 2009. Effect of garlic powder on egg yolk and serum cholesterol and performance of laying hens. Bulletin of the Veterinary Institute in Pulawy. 53: 515-519.

Carrijo, A. S., Madeira, L. A., Sartori, J. R., Pezzato, A. C., Gonçalves, J. C., Cruz, V.C. D., Kuibida, K. V. and Pinheiro, D. F. 2005. Powdered garlic in the alternative feeding of broiler chickens. Pesquisa Agropecuária Brasileira. 40:673-679.

Chaves, A. V., Stanford, K., Dugan, M. E. R., Gibson, L. L., McAllister, T. A., Van Herk, F. and Benchaar, C. 2008. Effects of cinnamaldehyde, garlic and juniper berry essential oils on rumen fermentation, blood metabolites, growth performance, and carcass characteristics of growing lambs. Livestock Science. 117: 215-224.

Chen, Y. J., Kim, I. H., Cho, J. H., Yoo, J. S., Wang, Q., Wang, Y. and Huang, Y. 
2008. Evaluation of dietary L - carnitine or garlic powder on growth performance, dry matter and nitrogen digestibilities, blood profiles and meat quality in finishing pigs. Animal Feed Science and Technology.141: 141-152.

El-Katcha, M. I., Soltan, M. A. and Essi, M. S. 2016. Effect of Garlic Extract Supplementation on Growth Performance, Nutrient Digestibility and Some Blood Serum Biochemical Changes of Fattening Lambs. Alexandria Journal for Veterinary Sciences. 48.

Faisal Irshad, Dr., HinaMawani, Dr. and Sana Naz, Dr. 2017. Effect Of Supplementation On Serum Triglycerides, Total Cholesterol, Hdlc, Ldlc And Blood Cell Counts In Albino Rats. The Professional Medical Journal.24: 612-616.

Ghalehkandi, J. G. 2012. Effect of Garlic (Allium sativum) Aqueous Extract (GAE) on Serum Values of Calcium (Ca), Phosphorous (P) and Alkaline Phosphatase (ALP) Compared with Chromium Chloride in Male Rats. American Journal of Scientific Research.77: 18-24.

Gupta, N. and Porter, T.D.2001. Garlic and garlic derived compounds inhibit human squalene monooxygenase. J. Nutr. 131:1662-1667.

Hassan, E. H. and Abdel-Raheem, S. M. 2013. Response of growing buffalo calves to dietary supplementation of caraway and garlic as natural additives. World Applied Sciences Journal.22: 408-414.

Hirasa, K. and Takemasa, M. 1998. Spice science and technology. CRC Press.

Jain, R. C. and Vyas, C. R. 1975. Garlic in alloxan-induced diabetic rabbits. The American Journal of Clinical Nutrition. 28: 684-685.

Jayasena, D. D. and Jo, C. 2013. Essential oils as potential antimicrobial agents in meat and meat products: A review. Trends in Food Science \& Technology. 34: 96108.

Kholif, S. M., Morsy, T. A., Abdo, M. M., Matloup, O. H. and El-Ella, A. A. 2012. Effect of supplementing lactating goats rations with garlic, cinnamon or ginger oils on milkyield, milk composition and milk fatty acids profile. Journal of Life Sciences 4:27-34.

Kumar, G. R. and Reddy, K. P. 1999. Reduced nociceptive responses in mice with alloxan induced hyperglycemia after garlic (Allium sativum) treatment. Indian Journal of Experimental Biology. 37: 662-666.

Kumar, R., Chhatwal, S., Arora, S., Sharma, S., Singh, J., Singh, N., Bhandari, V. and Khurana, A. 2013. Antihyperglycemic, antihyperlipidemic, anti-inflammatory and adenosine deaminase-lowering effects of garlic in patients with type 2 diabetes mellitus with obesity. Diabetes, metabolic syndrome and obesity: Targets and Therapy.6: 49.

Lamorde, A. 1996. The role of Veterinary medicine in developing economy. A paper presented during the week of Association of Veterinary Medical Students of the University of Maiduguri.

Lanzotti, V. 2006. The analysis of onion and garlic. J. Chrom., A 1112: 3-22.

Lee, Y.M., Gweon, O., Seo, Y.J., Im, J., Kang, M.J., Kim, M.J., Kim, J.I. 2009. Antioxidant effect of garlic and aged black garlic in animal model of type 2 diabetes mellitus. Nutr. Res. Pract. 3:156-161.

Mahmoud, K. Z., Gharaibeh, S. M., Zakaria, H. A. and Qatramiz, A. M. 2010. Garlic (Allium sativum) supplementation: Influence on egg production, quality, and yolk cholesterol level in layer hens. 
Asian-Australasian Journal of Animal Sciences. 23: 1503-1509.

Mirhadi, S. A., Singh, S. and Gupta, P. P. 1991. Effect of garlic supplementation to cholesterol rich diet on development of atherosclerosis in rabbits. Indian Journal of Experimental Biology. 29: 162-168.

Mitruka, B.M., Rawnshey, H.N. 1977. Clinical biochemical and haematological reference values in normal experimental Animals, Masson, New York.

Omojola, A. B., Fagbuaro, S. S. and Ayeni, A. A. 2009. Cholesterol content, physical and sensory properties of pork from pigs fed varying levels of dietary garlic (Allium sativum). World Applied Sciences Journal 6: 971-975.

Onu, P. N. and Aja, P. M. 2011. Growth performance and haematological indices of weaned rabbits fed garlic (Allium sativum) and ginger (Zingiber officinale) supplemented diets. International Journal of Food, Agriculture and Veterinary Sciences. 1: 51-59.

Onyimonyi, A. E. and Omeje, M. U. 2013.Bioevaluation of garlic on growth, haematological and serum characteristics of growing pigs. African Journal of Biotechnology. 12.

Oyawoye, E.O., Ogunkunle, M. 1998. Physiological and biochemistry effects of Raw Jack beans on broiler.Proc. Nig. Soc. Anim. Prod. 23:141-142.

Pirmohammadi, R., Anassori, E., Zakeri, Z. and Tahmouzi, M. 2014. Effects of garlic supplementation on energy status of pre-partum Mahabadi goats. Veterinary Research Forum 5: 207.

Platel, K., Rao, A., Saraswathi, G. and Srinivasan, K. 2002. Digestive stimulant action of three Indian spices mixes in experimental rats. Nahrung, 46(6): 394-398.
Prasad, R., Rose, M. K., Virmani, M., Garg, S. L. and Puri, J. P. 2009. Lipid profile of chicken (Gallus domesticus) in response to dietary supplementation of garlic (Allium sativum). International Journal of Poultry Science. 8: 270-276.

Puvaca, N., Kostadinovic, L., Ljubojevic, D., Lukac, D., Popovic, S., Dokmanovc, B. and Stanacev, V. S. 2014. Effects of dietary garlic addition on productive performance and blood lipid profile of broiler chickens. Biotechnology in Animal Husbandry. 30: 669-676.

Qureshi, A. A., Din, Z. Z., Abuirmeileh, N., Burger, W. C., Ahmad, Y. and Elson, C. E. 1983. Suppression of avian hepatic lipid metabolism by solvent extracts of garlic: impact on serum lipids. The Journal of Nutrition.113: 1746-1755.

Rahimi, S., TeymoriZadeh, Z., Torshizi, K., Omidbaigi, R. and Rokni, H. 2011. Effect of the three herbal extracts on growth performance, immune system, blood factors and intestinal selected bacterial population in broiler chickens. Journal of Agricultural Science and Technology.13: 527-539.

Ramprabhu, R., Chellapandian, M., Balachandran, S., Rajeswar, J.J. 2010. Influence of age and sex on blood parameters of Kanni goat in Tamil Nadu. Indian J Small Rumin. 16: 84-89.

Rhodes, M. J. C. 1996. Physiologically-active compounds in plant foods: An Overview. Proceedings of the Nutrition Society. 55: 371-384.

Singh, J., Sharma, M., Singh, N., Kaur, P., Sethi, A. P. S. and Sikka, S. S. 2017. Effect of sun dried whole bulb garlic powder on nutrient utilization, blood parameters, duodenum morphology and faecal microbial load in broiler chickens. Indian Journal of Animal Sciences. 87: 195-198.

Sodimu, O., Joseph, P. K. and Augusti, K. T. 1984. Certain biochemical effects of 
garlic oil onrats maintained on high fathigh cholesterol diet. Cellular and Molecular Life Sciences.40: 78-80.

SPSS, 2008. Statistical Packages for the social science, Release 16, SPSS INC, Chicago, USA.

Toghyani, M., Toghyani, M., Gheisari, A., Ghalamkari, G. and Mohammadrezaei, M. 2011. Growth performance, serum biochemistry and blood hematology of broiler chicks fed different levels of black seed (Nigella sativa) and peppermint (Mentha piperita). Livestock Science 129: 173-178.

Vazquez-Prieto, M. A., Rodriguez, L. C., Lembo, C., Galmarini, C. R., Miatello, R. M. 2011. Garlic and onion attenuates vascular inflammation and oxidative stress in fructose-fedrats. Journal of
Nutrition and Metabolism.

Wenk, C. 2003. Herbs and botanicals as feed additives in monogastric animals. Asian Australasian Journal of Animal Sciences. 16: 282-289.

Yan, L., Meng, Q. W., Ao, X., Zhou, T. X., Yoo, J. S., Kim, H. J. and Kim, I. H. 2011. Effects offermented garlic powder supplementation on growth performance, blood characteristics and meat quality in finishing pigs fed lownutrient-density diets. Livestock Science 137: 255-259.

Zakeri, Z., Pirmohammadi, R., Anassori, E. and Tahmouzi, M. 2014. Feeding raw garlic to dairy goats: effects on blood metabolites and lactation performance. Kafkas Universitesi Veteriner Fakultesi Dergisi.20: 399-404.

\section{How to cite this article:}

Mohan Vamsi Duvvu, K. Ananda Rao, Ch. Venkata Seshaiah and Srinivas Kumar, D. 2018. Effect of Garlic Supplementation on the Blood Biochemical Profile of Murrah Buffalo Calves. Int.J.Curr.Microbiol.App.Sci. 7(03): 2973-2983. doi: https://doi.org/10.20546/ijcmas.2018.703.344 